\title{
Penerapan Metode Multi Objective Optimization on The Basic of Ratio Analysis (MOORA) pada Pemilihan Masker Organik Wajah Berdasarkan Kriteria
}

\author{
Ade Dwi Amanda*, Fildzah Nadya Arieni, Agus Perdana Windarto \\ Program Studi Sistem Informasi, STIKOM Tunas Bangsa, Pematangsiantar, Indonesia \\ Email: 1," adedwiamanda99@gmail.com, ${ }^{2}$ fildzah.nadya17@gmail.com, ${ }^{3}$ agus.perdana@ amiktunasbangsa.ac.id \\ Submitted: 06/05/2021; Accepted: 22/05/2021; Published: 30/05/2021
}

\begin{abstract}
Abstrak-Masker organik merupakan masker yang terbuat dari bahan alami yang memiliki kandungan gizi yang baik untuk wajah. Masker organik memiliki banyak manfaat yang tentunya tidak kalah dari perawatan didokter kecantikan.Masker wajah adalah masker kecantikan yang berwujud sediaan gel, pasta dan serbuk yang dioleskan untuk membersihkan dan mengencangkan kulit terutama kulit wajah.Masker wajah juga berfungsi sebagai pembawa bahan-bahan aktif yang berguna bagi kesehatan kulit, seperti ekstra tumbuhan, minyak esensial, atau rumput laut yang dapat diserap oleh permukaan kulit untuk dibawa kedalam sirkulasi darah.Tujuan penelitian ini adalah untuk membantu para konsumen dalam menentukan masker organic wajah terbaik.Metode penelitian ini menggunakan metode MOORA. Kriteria yang digunakan yaitu Varian (A), Ukuran (B), Harga (C), Aroma (D), Cara Penggunaan (E), Aturan Penggunaan (F), Hasil Pemakaian (G). Alternatif yang digunakan adalah Crushlicious (0.1147), Namo.Id (0.2758), NHM (0.2257), Lea Gloria (0.7218), Poupeepou (0.1692), dan Natuna Oilvera (0.1157). Dengan demikian nilai terbaik dari ke enam alternative tersebut adalah Masker Organik Wajah Lea Gloria dengan nilai 0.7218 .
\end{abstract}

Kata Kunci: SPK; Masker Organik; Moora; Konsumen; Serbuk

Abstract-Organic masks are masks made from natural ingredients that have good nutritional content for the face. Organic masks have many benefits which are certainly no less than treatments at a beauty doctor. Facial masks are beauty masks in the form of gels, pastes and powders which are applied to clean and tighten the skin, especially facial skin. Face masks also function as carriers for active ingredients that are useful for skin health, such as extra plants, essential oils, or seaweed that can be absorbed by the skin's surface to be carried into the blood circulation. The purpose of this study is to help consumers determine the best organic face mask. This research method uses the MOORA method. The criteria used are Variant (A), Size (B), Price (C), Aroma (D), Method of Use (E), Rules of Use (F), Results of Use (G). The alternatives used are Crushlicious (0.1147), Namo.Id (0.2758), NHM (0.2257), Lea Gloria (0.7218), Poupeepou (0.1692), and Natuna Oilvera (0.1157). Thus, the best value of the six alternatives is the Lea Gloria Organic Face Mask with a value of 0.7218 .

Keywords: DSS ;Organic Masks; Moora; Consumer; Powder

\section{PENDAHULUAN}

Masker organik merupakan masker yang terbuat dari bahan alami yang memiliki kandungan gizi yang baik untuk wajah. Masker organik memiliki banyak manfaat yang tentunya tidak kalah dari perawatan didokter kecantikan[1].Masker wajah adalah masker kecantikan yang berwujud sediaan gel, pasta dan serbuk yang dioleskan untuk membersihkan dan mengencangkan kulit terutama kulit wajah.Masker wajah juga berfungsi sebagai pembawa bahan-bahan aktif yang berguna bagi kesehatan kulit, seperti ekstra tumbuhan, minyak esensial, atau rumput laut yang dapat diserap oleh permukaan kulit untuk dibawa kedalam sirkulasi darah. Masker wajah saat ini memiliki banyak bentuk seperti serbuk, pasta, ada juga yang berbentuk gel.Berbagai perusahaan kosmetik besar saat ini banyak mengeluarkan produk yang berbahan alami atau "back to nature". Masyarakat saat ini banyak yang beralih pada produk yang berbahan alami, keistimewaan masker dari bahan alami ini adalah tidak menimbulkan iritasi dan efek samping[2]. Seiring dengan perkembangan teknologi informasi, semakin bertambah pula kemampuan komputer dalam membantu penyelesaian permasalahanpermasalahan dalam berbagai bidang diantaranya Sistem Pendukung Keputusan berbasis komputer (Computer Based Decision Support System), sistem ini adalah suatu sistem berbasis komputer yang dirancang untuk meningkatkan efektivitas pengambilan dalam memecahkan masalah.

SPK merupakan sistem berbasis komputer dengan antarmuka antara mesin/komputer dan pengguna.Sistem pendukung keputusan secara umum didefenisikan sebagai sistem yang mampu menghasilkan pemecahan maupun penanganan masalah. Sistem pendukung keputusan tidak dimaksudkan untuk menggantikan peran pengambil keputusan, tapi untuk membantu dan mendukung pengambil keputusan[3]. Sistem Pendukung Keputusan (SPK) adalah salah satu cara mengorganisir informasi yang dimaksudkan untuk digunakan dalam membuat keputusan. Ada yang mendefinisikan bahwa system pendukung keputusan merupakan suatu pendekatan untuk mendukung pengambilan keputusan.Sistem pendukung keputusan menggunakan data, memberikan antarmuka pengguna yang mudah dan dapat menggabungkan pemikiran pengambil keputusan[4]. Sistem Pendukung Keputusan merupakan sistem berbasis komputer yang mampu menyelesaikan masalah dengan menghasilkan alternatif terbaik untuk mendukung keputusan yang akan diambil oleh pengambil keputusan [5], [6]. Banyak cabang ilmu komputer yang dapat menyelesaikan permasalahan yang bersifat kompleks.Salah satunya adalah kecerdasan buatan (Artificial Intelligence). Beberapa bidang AI seperti 
datamining [7]-[10], jaringan saraf tiruan [11]-[15], sistem pendukung keputusan [16]-[22] ,sistem pakar [23] dan lain-lain.

Berdasarkan masalah yang ada, peneliti melakukan penelitian dengan tujuan untuk membantu para konsumen dalam menentukan masker organik wajah terbaik.Berdasarkan penjelasan tersebut, peneliti menggunakan sistem pendukung keputusan untuk menyelesaikan masalah di atas karena berkaitan dengan perangkingan.Salah satu metode yang terdapat di sistem pendukung keputusan adalah metode Multi-Objective Optimization on the basis of Ratio Analysis (MOORA) yang dapat membantu konsumen dalam menentukan masker organic wajah yang baik.MOORA juga sangat sederhana, stabil, dan kuat, bahkan metode ini tidak membutuhkan seorang ahli di bidang matematika untuk menggunakannya serta membutuhkan perhitungan matematis yang sederhana. Hasil yang diperoleh lebih akurat dan tepat sasaran dalam membantu pengambilan keputusan serta mudah diimplementasikan .Metode ini memiliki tingkat selektifitas yang baik karena dapat menentukan tujuan dari kriteria yang bertentangan. Dimana kriteria dapat bernilai menguntungkan (benefit) atau yang tidak menguntungkan (cost) [24]. Dalam penelitian terdahulu metode MOORA juga digunakan dalam sistem pendukung keputusan dalam menentukan Pemilihan Bibit Cabai di Desa Bandar Siantar Kecamatan Gunung Malela dimana pada kasus tersebut metode ini dapat digunakan sebagai salah satu alat bantu yang petani dalam merekomendasikan bibit cabai terbaik sehingga dapat membantu petani dalam meningkatkan produksi cabai merah di kalangan petani. [25]; Sistem Pendukung Keputusan Pemilihan Ban Sepeda Motor Honda Dengan Metode Multi Objective Optimization on The Basic of Ratio Analysis (MOORA) [26]; dan Penentuan Penerima KIP Dengan Menggunakan Metode MOORA pada SD Negeri 124395 Pematangsiantar[27].

\section{METODE PENELITIAN}

Pengumpulan data dilakukan dengan studi pustaka yang terkait dengan penelitian guna mempermudah bagi peneliti dalam memperoleh data. Peneliti juga menggunakan metode wawancara dan dari setiap sampel produk untuk mengamati secara langsung objek penelitian yang sebenarnya terjadi di lapangan.

\subsection{Masker Wajah}

Masker wajah diciptakan di Inggris pada abad ke-18 oleh Madame Rowley.Masker wajah sering kali mengandung mineral, vitamin, dan sari buah, seperti kaktus dan mentimun.

\subsection{Multi-Objective Optimization on the basis of Ratio Analysis (MOORA)}

Metode MOORA adalah metode yang diperkenalkan oleh Brauers dan Zavadkas (2006).Metode yang relatif baru ini pertama kali digunakan oleh Brauers (2003) dalam suatu pengambilan dengan multi-kriteria. Metode MOORA memiliki tingkat fleksibilitas dan kemudahan untuk dipahami dalam memisahkan bagian subjektif dari suatu proses evaluasi kedalam kriteria bobot keputusan dengan beberapa atribut pengambilan keputusan [28]. Metode ini memiliki tingkat selektifitas yang baik karena dapat menentukan tujuan dari kriteria yang bertentangan. Dimana kriteria dapat bernilai menguntungkan (benefit) atau yang tidak menguntungkan $(\cos t)$.Metode MOORA dapat membantu dalam pengambilan keputusan suatu kasus, akan tetapi perhitungan dengan menggunakan metode MOORA ini hanya yang menghasilkan nilai terbesar yang akan terpilih sebagai alternatif yang terbaik [29].MOORA melakukan pendekatan secara bersamaan dalam mengoptimalkan dua atau lebih alternative [30]-[34]. Berikut ini langkah penyelesaian metode MOORA yaitu sebagai berikut:

a) Menginput nilai kriteria.

b) Membuat matriks keputusan

c) Normalisasi pada metode MOORA. Normalisasi bertujuan untuk menyatukan setiap element matriks sehingga element sehingga element pada matriks memiliki nilai yang seragam. Normalisasi pada MOORA dapat dihitung menggunakan persamaan sebagai berikut :

$$
\mathrm{X} * i j=\frac{\mathrm{X} i j}{-} \sqrt{\left[\sum_{\mathrm{i}=1}^{\mathrm{m}} X^{2} \mathrm{ij}\right]}
$$

d) Optimalkan Atribut. Untuk optimasi multi obyektif, pertunjukan normal ini ditambahkan dalam hal memaksimalkan (untuk menguntungkan atribut) dan dikurangi jika terjadi minimisasi (untuk atribut yang tidak menguntungkan). Maka masalah optimasi menjadi:

$$
Y i=\sum_{j}^{g}=1 X^{*} i j-\sum_{j}^{n}=g+1 X^{*} i j
$$

e) Mengurangi nilai maximax dan minmax untuk menandakan bahwa sebuah atribut lebih penting itu bisa dikalikan dengan bobot yang sesuai (Koefisien signifikasi). Saat atribut bobot dipertimbangkan perhitungan menggunakan persaman sebagai berikut.

$$
Y_{1=\Sigma_{j}^{g}=W J X^{*} i j-\sum_{j}^{n}=g+1 W j X^{*} i j}
$$

f) Menentukan ranking dari hasil perhitungan MOORA. 


\section{HASIL DAN PEMBAHASAN}

\subsection{Kriteria}

Dalam metode (MOORA) terdapat kriteria-kriteria yang dijadikan sebagai bahan perhitungan pada proses penilaian. Dalam penelitian ini digunakan tujuh kriteria.Setiap kriteria dilambangkan dengan C1, C2, C3, C4, C5, C6, dan C7. Adapun kriteria yang digunakan adalah Varian (C1), Ukuran (C2), Harga (C3), Aroma (C4), Cara Penggunaan (C5), Aturan Penggunaan (C6), Hasil Pemakaian (C7). Contoh data dari kriteria tersebut adalah:

Tabel 1. Data Kriteria

\begin{tabular}{cccc}
\hline Kriteria & Keterangan & Bobot & Jenis \\
\hline C1 & Varian & $15 \%$ & Benefit \\
C2 & Ukuran & $10 \%$ & Cost \\
C3 & Harga & $10 \%$ & Cost \\
C4 & Aroma & $20 \%$ & Benefit \\
C5 & Cara Penggunaan & $10 \%$ & Cost \\
C6 & Aturan Penggunaan & $10 \%$ & Cost \\
C7 & Hasil Pemakaian & $25 \%$ & Benefit \\
\hline
\end{tabular}

Tabel 2. Data Rating Kecocokan

\begin{tabular}{|c|c|c|c|c|c|c|c|c|}
\hline \multirow[t]{2}{*}{ No } & Alternatif & \multicolumn{5}{|c|}{ Kriteria } & & \\
\hline & & Varian & Ukuran & Harga & Aroma & $\begin{array}{c}\text { Cara } \\
\text { Penggunaan }\end{array}$ & $\begin{array}{c}\text { Aturan } \\
\text { Penggunaan }\end{array}$ & $\begin{array}{c}\text { Hasil } \\
\text { Pemakaian }\end{array}$ \\
\hline 1 & Crushlicious & Coklat & 25 gram & Murah & Wangi & Dioles & 1 Kali Seminggu & Lembab \\
\hline 2 & Namo.Id & Coffee & 50 gram & Sedang & $\begin{array}{l}\text { Kurang } \\
\text { Wangi }\end{array}$ & $\begin{array}{l}\text { Ditempel di } \\
\text { Wajah }\end{array}$ & 2 Kali Seminggu & Halus \\
\hline 3 & NHM & Lemonade & $\begin{array}{l}100 \\
\text { gram }\end{array}$ & Mahal & $\begin{array}{l}\text { Tidak } \\
\text { Wangi }\end{array}$ & $\begin{array}{l}\text { Di tap-tap di } \\
\text { wajah }\end{array}$ & 3 Kali Seminggu & Cerah \\
\hline 4 & Lea Gloria & Coklat & 50 gram & Sedang & Wangi & Dioles & 2 Kali Seminggu & Cerah \\
\hline 5 & Poupeepou & Coffee & 25 gram & Murah & Wangi & $\begin{array}{l}\text { Di tap-tap di } \\
\text { wajah }\end{array}$ & 1 Kali Seminggu & Lembab \\
\hline 6 & $\begin{array}{l}\text { Natuna } \\
\text { Oilvera }\end{array}$ & Coffee & 50 gram & Sedang & $\begin{array}{l}\text { Kurang } \\
\text { Wangi }\end{array}$ & Dioles & 1 Kali Seminggu & Lembab \\
\hline
\end{tabular}

\subsection{Pembobotan Kriteria}

a) Kriteria Varian (C1)

Tabel 3. Pembobotan Kriteria Varian

\begin{tabular}{ccc}
\hline Varian & Bobot & Nilai \\
\hline Coklat & Tinggi & 5 \\
Coffee & Sedang & 3 \\
Lemonade & Rendah & 1 \\
\hline
\end{tabular}

b) Kriteria Ukuran (C2)

Tabel 4. Pembobotan Kriteria Ukuran

\begin{tabular}{ccc}
\hline Ukuran & Bobot & Nilai \\
\hline 25 gram & Rendah & 1 \\
50 gram & Sedang & 3 \\
100 gram & Tinggi & 5 \\
\hline
\end{tabular}

c) Kriteria Harga (C3)

Tabel 5. Pembobotan Kriteria Harga

\begin{tabular}{ccc}
\hline Harga & Bobot & Nilai \\
\hline Mahal & Tinggi & 5 \\
Sedang & Sedang & 3 \\
Murah & Rendah & 1 \\
\hline
\end{tabular}

d) Kriteria Aroma (C4) 
Tabel 6. Pembobotan Kriteria Aroma

\begin{tabular}{ccc}
\hline Aroma & Bobot & Nilai \\
\hline Wangi & Tinggi & 5 \\
Kurang Wangi & Rendah & 1 \\
Tidak Wangi & Sedang & 3 \\
\hline
\end{tabular}

e) Kriteria Cara Penggunaan (C5)

Tabel 7. Pembobotan Kriteria Cara Penggunaan

\begin{tabular}{ccc}
\hline Cara Penggunaan & Bobot & Nilai \\
\hline Dioles & Tinggi & 5 \\
Ditempel di Wajah & Rendah & 1 \\
Di Tap-Tap di Wajah & Sedang & 3 \\
\hline
\end{tabular}

f) Kriteria Aturan Penggunaan (C6)

Tabel 8. Pembobotan Kriteria Aturan Penggunaan

\begin{tabular}{ccc}
\hline Aturan Penggunaan & Bobot & Nilai \\
\hline 1 Kali Seminggu & Rendah & 1 \\
2 Kali Seminggu & Tinggi & 5 \\
3 Kali Seminggu & Sedang & 3 \\
\hline
\end{tabular}

g) Kriteria Hasil Pemakaian (C7)

Tabel 9. Pembobotan Kriteria Hasil Pemakaian

\begin{tabular}{ccc}
\hline Hasil Pemakaian & Bobot & Nilai \\
\hline Lembab & Sedang & 3 \\
Halus & Tinggi & 5 \\
Cerah & Rendah & 1 \\
\hline
\end{tabular}

Setelah melakukan pembobotan pada data tersebut, maka dapat dilihat data kecocokan pada masingmasing alternative terhadap kriteria yang dapat dilihat pada Tabel 10.

Tabel 10. Rating Kecocokan

\begin{tabular}{|c|c|c|c|c|c|c|c|c|}
\hline \multirow{2}{*}{ No } & \multirow{2}{*}{ Alternatif } & \multicolumn{7}{|c|}{ Kriteria } \\
\hline & & $\mathrm{C} 1$ & $\mathrm{C} 2$ & C3 & $\mathrm{C} 4$ & $\mathrm{C5}$ & C6 & $\mathrm{C7}$ \\
\hline 1 & Crushlicious & 5 & 1 & 1 & 5 & 5 & 1 & 3 \\
\hline 2 & Namo.Id & 3 & 3 & 3 & 1 & 1 & 5 & 5 \\
\hline 3 & NHM & 1 & 5 & 5 & 3 & 3 & 3 & 1 \\
\hline 4 & Lea Gloria & 5 & 3 & 3 & 5 & 5 & 5 & 1 \\
\hline 5 & Poupeepou & 3 & 1 & 1 & 5 & 3 & 1 & 3 \\
\hline 6 & Natuna Oilvera & 3 & 3 & 3 & 1 & 5 & 1 & 3 \\
\hline
\end{tabular}

Berikut merupakan langkah penyelesaian metode MOORA:

a) Matriks Keputusan $\mathrm{X}_{\mathrm{ij}}$

$$
\mathrm{X}_{\mathrm{ij}}=\left[\begin{array}{lllllll}
5 & 1 & 1 & 5 & 5 & 1 & 3 \\
3 & 3 & 3 & 1 & 1 & 5 & 5 \\
1 & 5 & 5 & 3 & 3 & 3 & 1 \\
5 & 3 & 3 & 5 & 5 & 5 & 1 \\
3 & 1 & 1 & 5 & 3 & 1 & 3 \\
3 & 3 & 3 & 1 & 5 & 1 & 3
\end{array}\right]
$$

b) Matriks kinerja ternormalisasi

Kriteria $1(\mathrm{C} 1)$

$=\sqrt{5^{2}+3^{2}+1^{2}+5^{2}+3^{2}+3^{2}}=8.8317$

A $11=5 / 8.8317=0.5661$

A $21=3 / 8.8317=0.3396$

A $31=1 / 8.8317=0.1132$

A $41=5 / 8.8317=0.5661$

A $51=3 / 8.8317=0.1132$

A $61=3 / 8.8317=0.1132$

Kriteria 2 ( C2 ) 
$=\sqrt{1^{2}+3^{2}+5^{2}+3^{2}+1^{2}+3^{2}}=7.3484$

A $12=1 / 7.3484=0.1360$

A $22=3 / 7.3484=0.4082$

A $32=5 / 7.3484=0.6804$

A $42=3 / 7.3484=0.4082$

A $52=1 / 7.3484=0.1360$

A $62=3 / 7.3484=0.4082$

Kriteria 3 ( C3 )

$=\sqrt{1^{2}+3^{2}+5^{2}+3^{2}+1^{2}+3^{2}}=7.3484$

A $13=1 / 7.3484=0.1360$

A $23=3 / 7.3484=0.4082$

A $33=5 / 7.3484=0.6804$

A $43=3 / 7.3484=0.4082$

A $53=1 / 7.3484=0.1360$

A $63=3 / 7.3484=0.4082$

Kriteria 4 ( C4 )

$=\sqrt{5^{2}+1^{2}+3^{2}+5^{2}+5^{2}+1^{2}}=9.1651$

A $14=5 / 9.1651=0.5455$

A $24=1 / 9.1651=0.1091$

A $34=3 / 9.1651=0.3273$

A $44=5 / 9.1651=0.5455$

A $54=5 / 9.1651=0.5455$

A $64=1 / 9.1651=0.1091$

Kriteria 5 ( C5 )

$=\sqrt{5^{2}+1^{2}+3^{2}+5^{2}+3^{2}+5^{2}}=9.6953$

A $15=5 / 9.6953=0.5157$

A $25=1 / 9.6953=0.1031$

A $35=3 / 9.6953=0.3094$

A $45=5 / 9.6953=0.5157$

A $55=3 / 9.6953=0.3094$

A $65=5 / 9.6953=0.5157$

Kriteria 6 ( C6 )

$=\sqrt{1^{2}+5^{2}+3^{2}+5^{2}+1^{2}+1^{2}}=7.8740$

A $16=1 / 7.8740=0.1270$

A $26=5 / 7.8740=0.6350$

A $36=3 / 7.8740=0.3810$

A $46=5 / 7.8740=0.6350$

A $56=1 / 7.8740=0.1270$

A $66=1 / 7.8740=0.1270$

Kriteria 7 ( C7 )

$=\sqrt{3^{2}+5^{2}+1^{2}+1^{2}+3^{2}+3^{2}}=7.3484$

A $17=3 / 7.8740=0.4082$

A $27=5 / 7.8740=0.6804$

A $37=1 / 7.8740=0.1360$

A $47=1 / 7.8740=0.1360$

A $57=3 / 7.8740=0.4082$

A $67=3 / 7.8740=0.4082$

Berdasarkan perhitungan diatas, berikut ini adalah matriks kinerja ternormalisasi yaitu:

$\mathrm{X}_{\mathrm{ij}}=\left[\begin{array}{cccccccc}0.5661 & 0.1360 & 0.1360 & 0.5455 & 0.5157 & 0.1270 & 0.4083 \\ 0.3396 & 0.4082 & 0.4082 & 0.1091 & 0.1031 & 0.6350 & 0.6804 \\ 0.1132 & 0.6804 & 0.6804 & 0.3273 & 0.3094 & 0.3810 & 0.1360 \\ 0.5661 & 0.4082 & 0.4082 & 0.5455 & 0.5157 & 0.6350 & 0.1360 \\ 0.3396 & 0.1360 & 0.1360 & 0.5455 & 0.3094 & 0.1270 & 0.4082 \\ 0.3396 & 0.4082 & 0.4082 & 0.1091 & 0.5157 & 0.1270 & 0.4082\end{array}\right]$

Perkalian bobot disertakan pencarian y ternormalisasi. Maka nilai $\mathrm{X}_{\mathrm{ij}} * \mathrm{~W}_{\mathrm{j}}$ yaitu sebagai berikut: $\mathrm{W}_{\mathrm{j} 11}=0.15 * 0.5661=0.0849$ 


$$
\begin{aligned}
& \mathrm{W}_{\mathrm{j} 21}=0.15 * 0.3396=0.0509 \\
& \mathrm{~W}_{\mathrm{j} 31}=0.15 * 0.1132=0.0169 \\
& \mathrm{~W}_{\mathrm{j} 41}=0.15 * 0.5661=0.0849 \\
& \mathrm{~W}_{\mathrm{j} 51}=0.15 * 0.3396=0.0509 \\
& \mathrm{~W}_{\mathrm{j} 61}=0.15 * 0.3396=0.0509 \\
& \mathrm{~W}_{\mathrm{j} 12}=0.10 * 0.1360=0.0136 \\
& \mathrm{~W}_{\mathrm{j} 22}=0.10 * 0.4082=0.0408 \\
& \mathrm{~W}_{\mathrm{j} 32}=0.10 * 0.6804=0.0680 \\
& \mathrm{~W}_{\mathrm{j} 42}=0.10 * 0.4082=0.0408 \\
& \mathrm{~W}_{\mathrm{j} 52}=0.10 * 0.1360=0.0136 \\
& \mathrm{~W}_{\mathrm{j} 62}=0.10 * 0.4082=0.0408 \\
& \mathrm{~W}_{\mathrm{j} 13}=0.10 * 0.1360=0.0136 \\
& \mathrm{~W}_{\mathrm{j} 23}=0.10 * 0.4082=0.0408 \\
& \mathrm{~W}_{\mathrm{j} 33}=0.10 * 0.6804=0.0680 \\
& \mathrm{~W}_{\mathrm{j} 43}=0.10 * 0.4082=0.0408 \\
& \mathrm{~W}_{\mathrm{j} 53}=0.10 * 0.1360=0.0136 \\
& \mathrm{~W}_{\mathrm{j} 63}=0.10 * 0.4082=0.0408 \\
& \mathrm{~W}_{\mathrm{j} 14}=0.20 * 0.5455=0.1091 \\
& \mathrm{~W}_{\mathrm{j} 24}=0.20 * 0.1091=0.0218 \\
& \mathrm{~W}_{\mathrm{j} 34}=0.20 * 0.3273=0.0654 \\
& \mathrm{~W}_{\mathrm{j} 44}=0.20 * 0.5455=0.1091 \\
& \mathrm{~W}_{\mathrm{j} 54}=0.20 * 0.5455=0.1091 \\
& \mathrm{~W}_{\mathrm{j} 64}=0.20 * 0.1091=0.0218 \\
& \mathrm{~W}_{\mathrm{j} 15}=0.10 * 0.5157=0.0515 \\
& \mathrm{~W}_{\mathrm{j} 25}=0.10 * 0.1031=0.0103 \\
& \mathrm{~W}_{\mathrm{j} 35}=0.10 * 0.3094=0.0309 \\
& \mathrm{~W}_{\mathrm{j} 45}=0.10 * 0.5157=0.0515 \\
& \mathrm{~W}_{\mathrm{j} 55}=0.10 * 0.3094=0.0309 \\
& \mathrm{~W}_{\mathrm{j} 65}=0.10 * 0.5157=0.0515 \\
& \mathrm{~W}_{\mathrm{j} 16}=0.10 * 0.1270=0.0127 \\
& \mathrm{~W}_{\mathrm{j} 26}=0.10 * 0.6350=0.0635 \\
& \mathrm{~W}_{\mathrm{j} 36}=0.10 * 0.3810=0.0381 \\
& \mathrm{~W}_{\mathrm{j} 46}=0.10 * 0.6350=0.0635 \\
& \mathrm{~W}_{\mathrm{j} 56}=0.10 * 0.1270=0.0127 \\
& \mathrm{~W}_{\mathrm{j} 66}=0.10 * 0.1270=0.0127 \\
& \mathrm{~W}_{\mathrm{j} 17}=0.25 * 0.4083=0.1021 \\
& \mathrm{~W}_{\mathrm{j} 27}=0.25 * 0.6804=0.1701 \\
& \mathrm{~W}_{\mathrm{j} 37}=0.25 * 0.1360=0.034 \\
& \mathrm{~W}_{\mathrm{j} 47}=0.25 * 0.1360=0.034 \\
& \mathrm{~W}_{\mathrm{j} 57}=0.25 * 0.4082=0.1020 \\
& \mathrm{~W}_{\mathrm{j} 67}=0.25 * 0.4082=0.1020
\end{aligned}
$$

Hasil perhitungan dari perkalian antara $\mathrm{X}_{\mathrm{ij}} * \mathrm{~W}_{\mathrm{j}}$ yaitu sebagai berikut:

$\mathrm{W}_{\mathrm{j}}=\left[\begin{array}{ccccccc}0.0849 & 0.0136 & 0.0136 & 0.1091 & 0.0515 & 0.0127 & 0.1021 \\ 0.0509 & 0.0408 & 0.0408 & 0.0218 & 0.0103 & 0.0635 & 0.1701 \\ 0.0169 & 0.0680 & 0.0680 & 0.0654 & 0.0309 & 0.0381 & 0.034 \\ 0.0849 & 0.0408 & 0.0408 & 0.1091 & 0.0515 & 0.0635 & 0.034 \\ 0.0509 & 0.0136 & 0.0136 & 0.1091 & 0.0309 & 0.0127 & 0.1020 \\ 0.0509 & 0.0408 & 0.0408 & 0.0218 & 0.0515 & 0.0127 & 0.1020\end{array}\right]$

Kemudian setelah melakukan perkalian antara $\mathrm{X}_{\mathrm{ij}} * \mathrm{~W}_{\mathrm{j}}$ maka berikutnya adalah menghitung nilai Yi yang terlihat pada table dibawah ini: 
Tabel 11. Nilai Yi Pada Metode Moora

\begin{tabular}{lccc}
\hline \multicolumn{1}{c}{ Alternatif } & $\begin{array}{c}\text { Maximum } \\
(\mathrm{C} 2+\mathrm{C} 3+\mathrm{C} 4+\mathrm{C} 6+\mathrm{C} 7)\end{array}$ & $\begin{array}{c}\text { Minimum } \\
(\mathrm{C} 1+\mathrm{C} 5)\end{array}$ & Yi (Max-Min) \\
\hline Crushlicious (A1) & 0.2511 & 0.1364 & 0.1147 \\
Namo.Id (A2) & 0.337 & 0.0612 & 0.2758 \\
NHM (A3) & 0.2735 & 0.0478 & 0.2257 \\
Lea Gloria (A4) & 0.8582 & 0.1364 & 0.7218 \\
Poupeepou (A5) & 0.251 & 0.0818 & 0.1692 \\
Natuna Oilvera (A6) & 0.2181 & 0.1024 & 0.1157 \\
\hline
\end{tabular}

Tabel 12. Perangkingan Alternatif

\begin{tabular}{lcc}
\hline \multicolumn{1}{c}{ Alternatif } & Yi (Max) & Ranking \\
\hline Crushlicious (A1) & 0.1147 & 6 \\
Namo.Id (A2) & 0.2758 & 2 \\
NHM (A3) & 0.2257 & 3 \\
Lea Gloria (A4) & 0.7218 & 1 \\
Poupeepou (A5) & 0.1692 & 4 \\
Natuna Oilvera (A6) & 0.1157 & 5 \\
\hline
\end{tabular}

Pada tabel 12, maka dapat disimpulkan bahwa alternative ke-1 dapat direkomendasikan sebagai masker organic wajah terbaik adalah yang memiliki nilai Yi (max) tertinggi yakni masker organic Lea Gloria (A4) dengan nilai Yi $(\max )=0.7218$.

\section{KESIMPULAN}

Dari penelitian diatas, maka peneliti dapat mengambil kesimpulan, yaitu: Hasil penelitian menyebutkan bahwa metode MOORA dapat diterapkan dalam pemilihan masker organik dengan menggunakan 7 kriteria penilaian yaitu: varian $(\mathrm{C} 1)$, ukuran $(\mathrm{C} 2)$, harga $(\mathrm{C} 3)$, aroma $(\mathrm{C} 4)$, cara penggunaan $(\mathrm{C} 5)$, aturan penggunaan (C6), hasil pemakaian (C7) dan 6 alternatif masker organik, yaitu: Crushlicious (A1), Namo.Id (A2), NHM (A3), Lea Gloria (A4), Poupeepou (A5), Natuna Oilvera (A6). Hasil yang diperoleh dari penelitian yang dilakukan, bahwa metode MOORA (Multi-Objective Optimization on the basis of Ratio Analysis) dapat menyeleksi alternative dan melakukan perangkingan dalam melakukan rekomendasi masker organik terbaik berdasarkan kriteria-kriteria yang telahditentukan dimana alternative Lea Gloria (A4) sebagai masker organic wajah terbaik dengan nilai Yi $(\max )=0.7218$.

\section{REFERENCES}

[1] A. Thalia, M. Odetta, F. Matematika, and P. Alam, . "Pada kulit wajah,salah satu perawatan yang bisa dilakukan adalah dengan mencuci dengan sabun. Namun itu tidak cukup untuk melindungi wajah dari berbagai hal yang dapat merusak kulit wajah. Diusia sekarang ini,banyak cara yang bisa."

[2] E. S. Han and A. goleman, daniel; boyatzis, Richard; Mckee, “済無No Title No Title,” J. Chem. Inf. Model., vol. 53, no. 9, pp. 1689-1699, 2019.

[3] F. I.-R. P. Computer, "Implementasi Multi-Objective Optimization On The Basis Of Ratio Analysis (MOORA) Untuk Menentukan Kualitas Buah Mangga Terbaik,” vol. 5, no. 1, pp. 50-55, 2018.

[4] A. Revi, I. Parlina, and S. Wardani, "Analisis Perhitungan Metode MOORA dalam Pemilihan Supplier Bahan Bangunan di Toko Megah Gracindo Jaya,” J. Nas. Inform. dan Teknol. Jar., vol. 3, no. 1, pp. 95-99, 2018.

[5] S. P. Keputusan and G. Pegawai, "Penentuan Ranking Kenaikan Gaji," pp. 247-256.

[6] T. Limbong et al., Sistem Pendukung Keputusan: Metode \& Implementasi. Medan: Yayasan Kita Menulis, 2020.

[7] P. Purnamasari, W. Suyitno, R. E. Indrajit, and M. Fauzi, "Penerapan Data Mining Dalam Menangani," vol. 1, no. 2, pp. 53-60, 2017.

[8] Asmira, "Penerapan Data Mining untuk Mengklasifikasi Pola Nasabah Menggunakan Algoritma C4,5 pada Bank BRI Unit Andounohu Kendari,” J. Sist. Komput. dan Sist. Inf., vol. 1, no. 1, pp. 22-28, 2019.

[9] A. P. Windarto, "Penerapan Datamining Pada Ekspor Buah-Buahan Menurut Negara Tujuan Menggunakan K-Means Clustering Method," Techno.Com, vol. 16, no. 4, pp. 348-357, 2017.

[10] F. S. Iantoro, "Surat Pernyataan Artikel Skripsi Tahun 2017," Sist. Inf. Pendaftaran Siswa Baru Smk Al Huda Kota Kediri Berbas. Web Syst., vol. 02, no. 07, pp. 0-7, 2018.

[11] F. Ningsih, Fitrianingsih, and L. A. Didik, "Indonesian Physical Review," Indones. Phys. Rev., vol. 2, no. 3, pp. 1-8, 2019.

[12] F. Zola, "Jaringan Syaraf Tiruan Menggunakan Algoritma Backpropagation Untuk Memprediksi Prestasi Siswa," J. Teknol. Dan Open Source, vol. 1, no. 1, pp. 58-72, 2018.

[13] A. S. Ritonga and S. Atmojo, "Pengembangan Model Jaringan Syaraf Tiruan untuk Memprediksi Jumlah Mahasiswa Baru di PTS Surabaya (Studi Kasus Universitas Wijaya Putra)," J. Ilm. Teknol. Inf. Asia, vol. 12, no. 1, p. 15, 2018.

[14] R. Sovia and M. Yanto, "Jaringan Syaraf Tiruan Analisa Pengaruh Gizi Buruk Terhadap Perkembangan Balita dengan Algoritma Perceptron," J. Ilm. Media SISFO, vol. 12, no. 1, pp. 1003-1011, 2019. 
[15] H. S. A. W. Yuli Andriani, "Prediksi Ekspor Impor Migas Ina," Regist. J. Ilm. Teknol. Sist. Inf., vol. 4, no. 1, pp. 3040, 2018

[16] R. Umar, A. Fadlil, and Y. Yuminah, "Sistem Pendukung Keputusan dengan Metode AHP untuk Penilaian Kompetensi Soft Skill Karyawan,” Khazanah Inform. J. Ilmu Komput. dan Inform., 2018.

[17] W. S. Prasetya, . K., and H. Al Fatta, "Sistem Pendukung Keputusan Pemilihan Produk Asuransi Studi Kasus : PT Commonwealth Life Pontianak," Sisfotenika, vol. 8, no. 1, p. 105, 2018.

[18] A. K. VADREAS, R. TURAINA, and S. ARDIANSYAH, "Sistem Penunjang Keputusan Penentuan (Spk) Bantuan Dana Pembangunan Rumah Tidak Layak Huni (Rtlh) Dengan Metode Multi Factor Evoluation Process (Mfep)," J. Teknoif, vol. 6, no. 1, pp. 18-23, 2018.

[19] Y. J. Sy and W. Marna, "Sistem Pendukung Keputusan Pemilihan Bayi Sehat," Sist. Pendukung Keputusan Pemilihan Bayi Sehat, vol. 2, no. Jurnal Edik Informatika, pp. 88-94, 2017.

[20] Sriani and R. A. Putri, "Analisa Sistem Pendukung Keputusan Mengunakan Metode TOPSIS Untuk Sistem Penerimaan Pegawai Pada SMA Al Washliyah Tanjung Morawa," J. Ilmu Komput. dan Inform., vol. 02, no. April, pp. 40-46, 2018.

[21] R. K. Tiony, N. H. Wardani, and T. Afirianto, "Sistem Pendukung Keputusan Pemilihan Produk Promo Dengan Menggunakan Metode Analytical Hierarchy Process - Simple Additive Weighting ( AHP - SAW ) ( Studi Kasus: Geprek Kak Rose )," J. Pengemb. Teknol. Inf. dan Ilmu Komput., vol. 3, no. 9, pp. 8413-8422, 2019.

[22] E. Ningsih, "Usaha Makanan Yang Tepat Menggunakan Weighted Product (WP) Berbasis Web," Ilk. J. Ilm., vol. 9, no. 3, pp. 244-254, 2017.

[23] I. H. Santi and B. Andari, "Sistem Pakar Untuk Mengidentifikasi Jenis Kulit Wajah dengan Metode Certainty Factor," INTENSIF J. Ilm. Penelit. dan Penerapan Teknol. Sist. Inf., vol. 3, no. 2, p. 159, 2019.

[24] J. Sianturi, "Sistem Pendukung Keputusan Pemilihan Anggota Polri Terbaik Dengan Menerap Kan Metode Moora (Multi Objective Optimization on the Basis of Rasio Analysis) (Studi Kasus : Polres Deli Serdang)," J. Pelita Inform., vol. 18 , pp. 358-364, 2019.

[25] C. Fadlan, A. P. Windarto, and I. S. Damanik, "Penerapan Metode MOORA pada Sistem Pemilihan Bibit Cabai (Kasus: Desa Bandar Siantar Kecamatan Gunung Malela)," J. Appl. Informatics Comput., vol. 3, no. 2, pp. 42-46, 2019.

[26] M. Safii and A. Zulhamsyah, "Sistem Pendukung Keputusan Pemilihan Mekanik Sepeda Motor Yamaha Alfascorfii Dengan Metode Multi Objective Optimization On The Basis Of Ratio Analysis (MOORA)," J-SAKTI (Jurnal Sains Komput. dan Inform., vol. 2, no. 2, p. 162, 2018.

[27] R. F. Sinaga, S. R. Andani, and S. Suhada, "Penentuan Penerima Kip Dengan Menggunakan Metode Moora Pada Sd Negeri 124395 Pematang ISiantar,” KOMIK (Konferensi Nas. Teknol. Inf. dan Komputer), vol. 2, no. 1, pp. 278-285, 2018 .

[28] S. Manurung, "Sistem Pendukung Keputusan Pemilihan Guru Dan Pegawai Terbaik Menggunakan Metode Moora," Simetris J. Tek. Mesin, Elektro dan Ilmu Komput., vol. 9, no. 1, pp. 701-706, 2018.

[29] S. Wardani and A. Revi, "Analisis Sistem Pendukung Keputusan Penyeleksian Siswa Calon Peserta Olimpiade Dengan Metode MOORA,” J. Teknovasi, vol. 05, no. 01, p. 18, 2018.

[30] K. N. A. Nur, S. R. Andani, and P. Poningsih, "Sistem Pendukung Keputusan Pemilihan Operator Seluler Menggunakan Metode Multi-Objective Optimization on the Basis of Ratio Analysis (Moora)," KOMIK (Konferensi Nas. Teknol. Inf. dan Komputer), vol. 2, no. 1, pp. 61-65, 2018.

[31] A. T. Hidayat, N. K. Daulay, and Mesran, "Penerapan Metode Multi-Objective Optimization on The Basis of Ratio Analysis (MOORA) dalam Pemilihan Wiraniaga Terbaik," J. Comput. Syst. Informatics, vol. 1, no. 4, pp. 367-372, 2020.

[32] N. K. Daulay, B. Intan, and M. Irvai, "Comparison of the WASPAS and MOORA Methods in Providing Single Tuition Scholarships," IJICS (International J. Informatics Comput. Sci., vol. 5, no. 1, pp. 84-94, 2021.

[33] S. Sutarno, M. Mesran, S. Supriyanto, Y. Yuliana, and A. Dewi, "Implementation of Multi-Objective Optimazation on the Base of Ratio Analysis (MOORA) in Improving Support for Decision on Sales Location Determination," in Journal of Physics: Conference Series, 2019.

[34] J. Afriany, L. Ratna, S. Br, I. Julianty, and E. L. Nainggolan, "Penerapan MOORA Untuk Mendukung Efektifitas Keputusan Manajemen Dalam Penentuan Lokasi SPBU,”vol. 5, no. 2, pp. 161-166, 2018. 